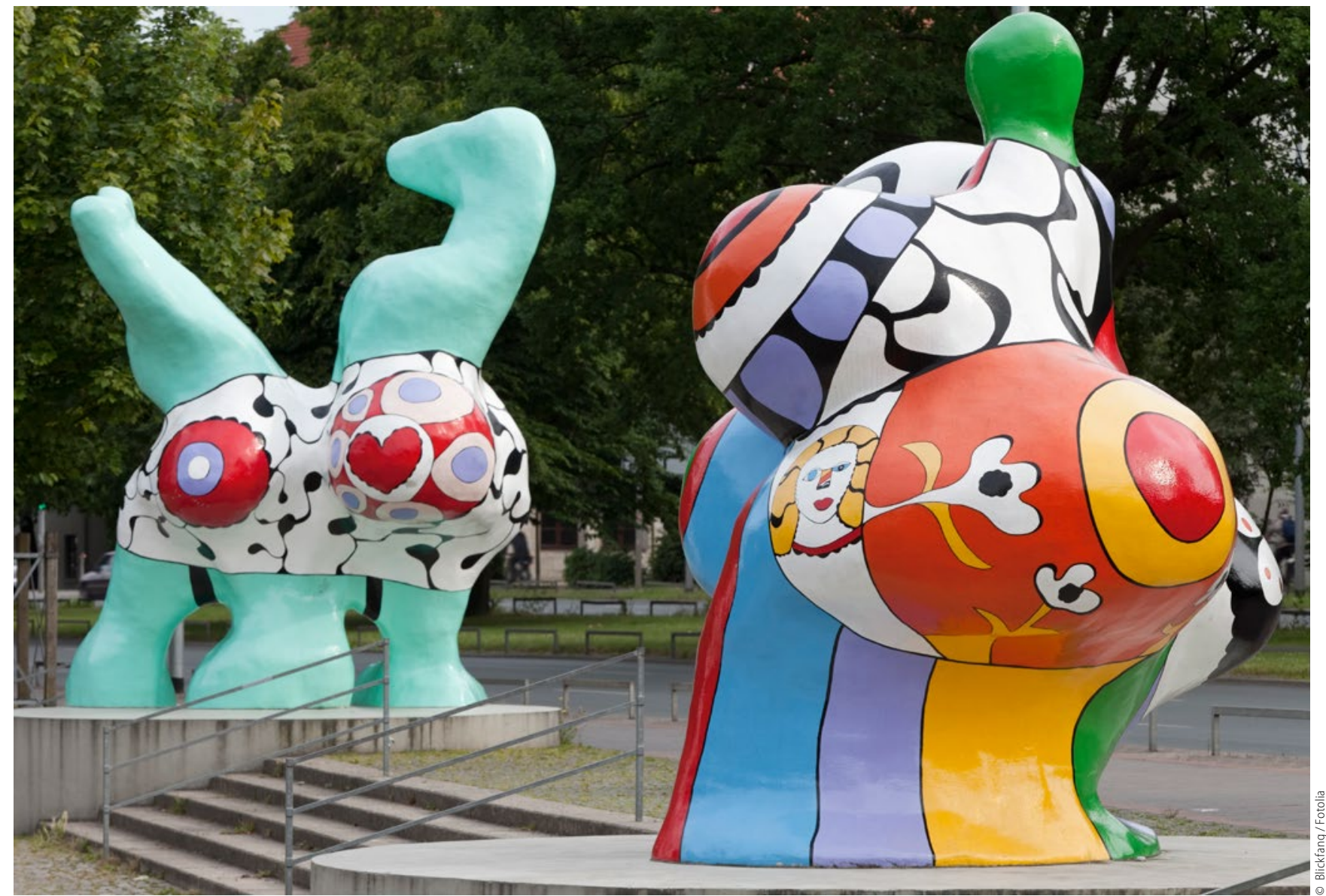

Tagesordnung

\title{
Hauptversammlung 2016 in Hannover
}

Tagungsort: MARITIM Airport Hotel Hannover, Saal „Maritim“, Flughafenstraße 5, 30669 Hannover Tel.: 0511 - 9737(0) / Fax: 0511 - 9737592

\section{Eröffnung der Hauptversammlung}

06.10.2016 Beginn/Ende: $\quad 09.30$

\section{Fortsetzung der Hauptversammlung}

07.10.2016 Beginn/Ende: 09:00

und

08.10 .2016

Beginn/Ende:

09:00

bis ca. 18:00 Uhr

bis ca. 13:00 Uhr

1. Eröffnung durch den Versammlungsleiter

2. Grußworte

3. Festreferat

4. Diskussion zum Festreferat

5. Regularien

6. Fragestunde

(Die Fragen dürfen sich nicht auf Punkte der Tagesordnung beziehen und müssen mindestens 1 Woche vor der Sitzung der Hauptversammlung in der Bundesgeschäftsstelle schriftlich eingegangen sein.)
7. Bericht des Bundesvorstandes

8. Diskussion des Berichts des Bundesvorstandes
a) Kernthema Freiberuflichkeit
b) Kernthema MVZ
c) Kernthema PAR
d) Allgemeine Diskussion entsprechend Raster

9. Änderung der Satzung

10. Bericht der Kassenprüfer

11. Jahresrechnung 2015

12. Entlastung des Bundesvorstandes

13. Änderung der Reisekostenordnung

14. Genehmigung des Haushaltes 2017

15. Anträge

(Anträge, die die Tagesordnung verändern, müssen spätestens 2 Wochen vor der Sitzung schriftlich in der Bundesgeschäftsstelle eingegangen sein.)

16. Verschiedenes 